\title{
New Insight into the Transformation of the Growth Mode of Foreign Trade
}

\author{
Xiaoming Qiao \\ Journal Editorial Department, Yunnan Normal University, Kunming City, \\ Yunnan Province, 650092, China
}

\begin{abstract}
The quantitative and extensive trade pattern in China is not in conformity with the requirement of safety, profitability and sustainability of economic development. Developing service trade is the key to the transformation of Chinese foreign trade growth mode. The countermeasures and suggestions were proposed in this paper to promote the change of the foreign trade pattern through the development of service trade.

Keywords: service trade; growth pattern; economic benefits
\end{abstract}

\section{The connotation of foreign trade growth mode}

Before the transformation of the foreign trade growth mode was written in "the 11 th five-year plan" in China, there is no complete and accurate scientific concept of foreign trade growth mode both at home and abroad, no clear definition of its connotation and denotation, and no reasonable division of various types of foreign trade growth mode. We hold that the transformation of the foreign trade growth mode is for promotion of economic growth in essence. Foreign trade growth is one aspect of economic growth, and promotes the economic growth. Economic growth is the external macro environment of foreign trade growth. They supplement each other[1]. The transformation of foreign trade growth mode should adapt to the economic growth mode. At the same time, it should be noted that the foreign trade growth mode should conform to the strategic objectives of sustainable development. Specifically, foreign trade growth mode is the ways to achieve the purpose of foreign trade profit growth and to promote economic 
development.

\section{Existing problems of Chinese foreign trade growth mode}

\subsection{The inconformity between Chinese foreign trade growth mode and the security of economic growth}

First, the trade surplus remains high and trade friction is increasing. For a long time, the mercantilist trade policy, namely emphasis on export and neglect of import, has been implemented in China, which results in Chinese foreign trade balance maintaining trade surplus as a whole, and increasing year by year. The huge trade surplus directly leads to the imbalance in Chinese international balance of payments, and the increase in international reserves, which exacerbates the pressure of $\mathrm{RMB}$ appreciation, and induces the continuous increase trade friction between China and her trade partners[2]. According to relevant statistics of the WTO, about one sixth of the anti-dumping cases initiated by WTO members point at China, which is extremely disproportionate to the fact that Chinese export accounts for only one-thirteenth of the world's total exports. Second, the concentration degree of foreign trade market is high. The distribution of foreign trade pattern, that is, the regional structure of foreign trade is an important indicator that reflects the ties between foreign trade development of a country or a region and international economic. It includes trade flows, the number of trading partners and the concentration degree of trade markets. If too much dependence is placed on a small number of markets, the export growth is bound to be limited. From the current geographical distribution of Chinese trade, the concentration degree of foreign trade market is relatively high[3].

\subsection{The inconformity between Chinese foreign trade growth mode and profitability of economic growth}

First, the trade structure is irrational and the core competitiveness is insufficient. In the era of global service development, the development of Chinese service trade and goods trade is extremely uneven. In 2007, Chinese service trade exports and imports accounted for $9.08 \%$ and $11.91 \%$ of the total foreign trade exports and imports, respectively, which are lower than the world average level of $19.37 \%$ and $18 \%$. As China lacks her own technology and brand, the foreign trade lacks the core competitiveness and the benefit is poor.

Second, the terms of trade continue to deteriorate and the trade efficiency is not high. The terms of trade is the ratio between export prices and import prices. From 1986 to 2004, the price terms of trade at this stage significantly inclined to the lower right direction. Although there was a rebound in 1987, 1991 and 1993, it has declined significantly since 1994, and the index of price trade terms declined from 119.5 in 1994 to 98.3 in 2004 , namely a decrease of $17.7 \%$. 


\subsection{The inconformity between Chinese foreign trade growth mode and the sustainability of economic growth}

First, the comparative advantage supported by low factor prices is not sustainable. Since the reform and opening up, China has made great efforts to develop lowtech labor-intensive export-oriented industries to achieve high-speed growth of foreign trade, which relies on low wage and low land cost. At present, our average wage is about $1 / 40$ of the major developed countries, and also lower than most developing countries. The land price can not reflect its true cost. However, with the increase of economic development level, this low-cost extensive foreign trade growth mode is unsustainable. Due to the continuous development of world economic integration and the increasing diversity of trade protection content, the technical standards for export products and the related requirements of health and safety are increasingly demanding, and the anti-dumping phenomenon will significantly increase[4]. The labor-intensive and low-cost advantages of Chinese products will be offset, and low-tech products will also reduce international competitiveness, which weakens comparative advantage and comparative interests.

Second, the trade mode of high resource consumption is not sustainable. Chinese economy and trade have been extensive growth mode for a long time. The output energy consumption and resource consumption are obviously higher than the international advanced level. The supply of important resources and energy is seriously insufficient. The per capita resources are far below the world level. In the case of relatively scarce resources, the dependence of energy and important resources on import is becoming increasingly serious. Although the large imports of important foreign resources and raw materials has made up for the domestic demand gap and supported the economic growth, the high dependence on foreign markets can easily lead to supply-demand and price risk, which not only is difficult to ensure the stable supply, but also promotes the increase in raw material prices. Finally, the foreign trade growth mode relying on the low cost of production factors can never sustain[5].

\section{Develop service trade to promote transformation of foreign trade growth mode}

\subsection{Strive to develop productive services, and improve the profit margins of goods trade}

The relationship between service trade and goods trade is interdependent and mutual promotion. The exertion of goods trade advantage and the enhancement of competitiveness are closely related to the development of related service trade. Productive services such as equipment installation, commissioning, technical guidance, quality control, inspection and maintenance have become the main source of products value addition. The productive services considered as middle 
input such as product development, design, business services is the basis of the promotion of the manufacturing industry towards high degree of processing, high value addition and high technology. Therefore, we can enlarge the profit space of goods trade, improve the deteriorating trade condition and turn quantitative growth to benefit growth by striving to develop the productive service of our country and strengthening the interaction of service trade and goods trade. Specifically, we should build up the manufacturing industry and service industry integration mechanism and environment, speed up the development of corresponding service industries, accelerate the professional division and cooperation of manufacturing industry and service industry, increase the demand for productive services, and form the good linked development pattern that goods trade stimulates service trade and service trade supports goods trade[6]. Besides, we should make full use of international resources and foreign investment to develop the productive service trade.

\subsection{Promote industrial upgrade by service trade import}

Developing service trade includes the development of exports and imports, which cannot be neglected. In terms of the current level and condition of Chinese service trade, it is inevitable and reasonable for China to maintain a certain service trade deficit in the future for a long time. Although the short-term import of service trade is a negative effect for our residents, and reduces the national profit, in the long term, the introduction of advanced technology can bring us the lacking technology and equipment, improve the knowledge and technology content of service industry, and promote the optimization of the service industry structure. Additionally, the introduction of scientific management methods and advanced marketing tools can raise service level and improve the backwardness of service trade, which could promote the growth of service trade exports. Foreign practice has proved that the introduction of advanced technology from abroad can bring the benefits via "late-breaking advantages". China should make full use of service trade as the main channel of technology introduction on the basis of open-up[7]. We can transfer technology directly from foreign countries through import of service trade, or import foreign trade through importing foreign direct investment. The latter usually takes multinational corporations as the main body, which tends to adopt localization strategy. In this manner, we can obtain the technology, and the digestion, absorption and even innovation can also be coducted in the process of technology spillover, which will promote the upgrade of Chinese industrial development and enhance international competitiveness.

\subsection{Expand a broader overseas trade market through Mode Three}

Mode Three namely "commercial existence" is one of the important ways to provide service trade. Export service trade via institution establishment through overseas investment not only can understand the need of customers in close distance, but also has a positive significance for increasing the international visibility of Chinese enterprises and enhancing the brand value. At the same time, the use of physical model to open up overseas markets is more conducive to the 
promotion of business service standards. For our manufacturing enterprises, the after-sales services provided by domestic service companies for their own equipments or completed projects can improve the foreign customers' satisfaction degree of products and engineering, win a good market reputation, and enhance international competitiveness. Therefore, we should select a number of domestic service enterprises with strong potentials and encourage them to go abroad to set up branches. In terms of the investment choice, we can jump out of the circle of the past goods trade objects, and expand a broader market, which will lay a good foundation for the entrance of goods trade into a new markets.

\subsection{Deal well with the relationship between open-up and competition, and} adopt the principle of gradual and moderate liberalization

The liberalization of service trade is the inevitable trend of world economic development. We should follow this trend and open up the service trade market. Moderate open-up of Chinese service trade market can not only introduce advanced technology and management experience, but also increase competition, break the monopoly of many service industries, and promote domestic service enterprises to improve competitiveness. However, the service industry plays a decisive role in the economic development and social stability of a country, and thus open-up cannot be too hasty. Compared with the developed countries, the service industry and service trade of our country with the overall lower level are late, and many industries are still in their infancy. Therefore, it is necessary to implement a mode of gradual liberalization with limited open-up. According to the needs of Chinese economic development and industrial restructuring, the gradual open-up can be conduced in various sectors, regions, modes and contents. Appropriate protective measures should be taken in service industries that involve the political, military and cultural security of our country. At the same time, full use should be made of the special preferential treatment, grace period and protection measures granted to the developing countries in the Agreement on Service Trade for the best interests.

\section{References}

[1] HE Yongda. On theoretical study of the transforming foreign trade growth pattern. Journal of Lishui University, (06), pp.41-45, 2008.

[2] JIAN Xinhua, ZHANG Hao. Study on transformation of China's foreign trade growth mode. China Industrial Economy, (08), pp.32-40, 2007.

[3] LI Qing. Economic thinking on transforming growth mode of foreign trade. Study \& Exploration, (02), pp.168-171, 2007.

[4] LUO Zhisong. Some thoughts on change China's foreign trade growth mode. World Economy Study, (02), pp.73-74, 2007.

[5] WANG Qiyun, CAI Zele, WANG Guojie. The new consideration on switching the growth way of Fforeign trade in China. Journal of Shijiazhuang University of Economics, (01), pp.43-47, 2006. 
[6] ZENG Weifeng. Reflections on the transformation of China's foreign trade growth mode. International Economics and Trade Research, (02), 33-37,1998.

[7] ZHAO Yongqing. Thinking on transformation of foreign trade growth mode. International Trade, (03), pp.26-28,1996. 